\title{
Does perceived support in employee development affect personnel turnover?
}

Citation for published version (APA):

Koster, F., de Grip, A., \& Fouarge, D. (2011). Does perceived support in employee development affect personnel turnover? International Journal of Human Resource Management, 22(11), 2403-2418.

https://doi.org/10.1080/09585192.2011.584404

Document status and date:

Published: 01/01/2011

DOI:

10.1080/09585192.2011.584404

Document Version:

Publisher's PDF, also known as Version of record

Document license:

Taverne

Please check the document version of this publication:

- A submitted manuscript is the version of the article upon submission and before peer-review. There can be important differences between the submitted version and the official published version of record.

People interested in the research are advised to contact the author for the final version of the publication, or visit the DOI to the publisher's website.

- The final author version and the galley proof are versions of the publication after peer review.

- The final published version features the final layout of the paper including the volume, issue and page numbers.

Link to publication

\footnotetext{
General rights rights.

- You may freely distribute the URL identifying the publication in the public portal. please follow below link for the End User Agreement:

www.umlib.nl/taverne-license

Take down policy

If you believe that this document breaches copyright please contact us at:

repository@maastrichtuniversity.nl

providing details and we will investigate your claim.
}

Copyright and moral rights for the publications made accessible in the public portal are retained by the authors and/or other copyright owners and it is a condition of accessing publications that users recognise and abide by the legal requirements associated with these

- Users may download and print one copy of any publication from the public portal for the purpose of private study or research.

- You may not further distribute the material or use it for any profit-making activity or commercial gain

If the publication is distributed under the terms of Article $25 \mathrm{fa}$ of the Dutch Copyright Act, indicated by the "Taverne" license above, 


\section{Does perceived support in employee development affect personnel turnover?}

Fleur Koster , Andries de Grip \& Didier Fouarge

To cite this article: Fleur Koster , Andries de Grip \& Didier Fouarge (2011) Does perceived support in employee development affect personnel turnover?, The International Journal of Human Resource Management, 22:11, 2403-2418, DOI: 10.1080/09585192.2011.584404

To link to this article: https://doi.org/10.1080/09585192.2011.584404

曲 Published online: 28 Jul 2011.

Submit your article to this journal \lceil

Џll Article views: 2160

Q View related articles $\asymp$

4 Citing articles: 19 View citing articles 


\title{
Does perceived support in employee development affect personnel turnover?
}

\author{
Fleur Koster ${ }^{\mathrm{a}}$, Andries de Grip ${ }^{\mathrm{b}, \mathrm{c}}$ and Didier Fouarge ${ }^{\mathrm{b} *}$ \\ ${ }^{a}$ Joanknecht \& Van Zelst, Eindhoven, The Netherlands; ${ }^{b}$ Research Centre for Education and the \\ Labour Market, Maastricht University, Maastricht, The Netherlands; ${ }^{c} I Z A$, Bonn, Germany
}

This article focuses on whether it is beneficial for firms to invest in the general skills of their workforce or whether these training investments merely encourage personnel turnover. Estimation results derived from a sample of 2833 Dutch pharmacy assistants show that participation in general training does not induce employees' intention to quit, as predicted by human capital theory. We find that a firm's investments in general training significantly contribute to the perceived support in employee development (PSED) among the workforce, as predicted by social exchange theory. Moreover, we show that PSED is negatively related to employees' intention to quit the firm; however, this effect is to a large extent mediated by employee job satisfaction. Our findings support the importance of social exchange theory in explaining turnover behaviour as a consequence of personnel development practices.

Keywords: human capital theory; intention to quit; job satisfaction; social exchange theory; training

\section{Introduction}

Training and development practices constitute one of the most important ways to assist personnel in gaining new knowledge and skills required to adhere to competitive standards (Tsai and Tai 2003). As acquiring knowledge is vital for organisations, appropriate training and development practices are decisive factors in a firm's success (Martin, Pate and McGoldrick 1999).

Within the literature, two perspectives on investing in employee development are widely acknowledged. The first perspective on the relation between training and development and personnel turnover stems from human capital theory. It suggests that investing in employee development can contribute to the market value of employees and hence induces turnover. Investments in general skills training are of particular interest, as this type of training also increases the productivity of employees for organisations other than the incumbent firm (Becker 1962). For this reason, human capital theory assumes that firms will not pay for such training; however, several studies have shown that firms usually contribute to the training costs when their workers participate in general training (Benson, Finegold and Mohrman 2004).

The other perspective, however, advances that by investing in the development of employees, their turnover intention decreases (Benson et al. 2004; Sieben 2007). Several studies have found that human resource development (HRD) practices affect the behaviour and attitudes of employees (Guest 2002; Edgar and Geare 2005; Muse and Stamper 2007). Moreover, Lee and Bruvold (2003) found that firms' investments in training their

*Corresponding author. Email: d.fouarge@maastrichtuniversity.nl 
workforce contribute to the creation of positive perceptions in employees of the organisation's willingness to support their development. These perceptions are related to the psychological contract and embedded in the context of social exchange theory (Blau 1964; Eisenberger, Huntington, Hutchison and Sowa 1986). Positive perceptions cause employees to believe in a social exchange relationship between themselves and the organisation, which makes them act in a reciprocal manner (Wayne, Shore and Liden 1997; Lee and Bruvold 2003). Such positive perceptions induce higher levels of job satisfaction and a stronger willingness to work hard to contribute to the organisation's higher performance (Arthur 1994; Eisenberger, Armeli, Rexwinkel, Lynch and Rhoades 2001). The relation between job satisfaction and labour market behaviour has received a lot of attention in the literature (see, e.g. Clark, Georgellis and Sanfey 1998). Evidence suggests that overall dissatisfaction with the job is a major predictor of intention to quit and that dissatisfaction with promotion and training opportunities has an even stronger effect (Shields and Ward 2001).

To this day, it is unclear whether it is human capital theory or social exchange theory that provides the best explanation for turnover behaviour, and we contribute to the literature by shedding light onto this issue. Although most studies have investigated the relation between the investments of firms in employee development and personnel turnover from either a social exchange or a human capital perspective, the goal of this article is to approach the problem by adding the human capital perspective to the social exchange model, which we further develop in this study. First, we investigate the effect of general training on quit behaviour as predicted in the human capital literature. Second, we explicitly test the major hypothesis from social exchange theory that general training is a predecessor of employees' perceptions of employer support. Third, we investigate how employees' perceptions are associated with their intention to quit and to what extent this relation mediates the effect of general training on intention to quit. Fourth, we examine whether job satisfaction plays a mediating role in the relation between employees' perceptions of employer support and intention to quit. Finally, we repeat the analysis with a distinction between (1) workers' intention to quit for a similar job in another firm in the same sector and (2) the intention to quit for another occupation. To study this matter in a homogenous group of employees, we utilise an employee data-set of Dutch pharmacies that consists solely of female workers with the same vocational education background.

This article is organised as follows: The following section briefly discusses the literature on human capital theory, social exchange theory and prior research on the relation between job satisfaction and turnover intention. It also outlines our hypotheses. We then describe our research methodology and discuss the results of our empirical analyses. The last section presents our conclusions and discusses the limitations of our analysis as well as suggestions for further research.

\section{Theoretical background and hypotheses}

\section{Human capital perspective and turnover intention}

Most studies on the effect of training on personnel turnover approach the issue from the point of view of human capital theory. According to this theory, investment in training contributes to an increase in worker productivity. Becker (1962), as the major initiator of human capital theory, distinguishes between two types of training: specific and general. Specific training is defined as the acquisition of competences that can hardly be transferred to other firms. It therefore only raises employee productivity within the firm. Employers 
are able to recoup all the costs and receive the full benefits but nevertheless face the risk that employees will quit. Therefore, according to the theory, both the employer and the employee are expected to pay for this type of training to create a mutual commitment that will diminish turnover intention.

General training, however, generates competences and qualifications that are of equal value to organisations other than the training firm. As a consequence, personnel turnover increases because employees can easily be poached by other organisations (Green, Felstead, Mayhew and Pack 2000). Although most studies on training and personnel turnover do not distinguish between general and specific training, or merely focus on firm-specific training (Bishop 1997), a few empirical studies provide some evidence for the human capital perspective, indicating that as a consequence of general training participation, workers' turnover increases (Bedeian, Kemery and Pizzolatto 1992; Benson et al. 2004; Sieben 2007).

Most theoretical models of turnover integrate one or more turnover cognitions as direct precursors of turnover. The intention to quit is such as cognition and is verified as a highly significant determinant of actual turnover (Steel and Ovalle 1984; Herrbach, Mignimac and Gatignon 2004). This leads to the following research hypothesis:

Hypothesis 1 (H1): The intention of employees to quit their current employer is positively related to participation in general training.

\section{Social exchange perspective and turnover intention}

Social exchange theory defines the employer-employee relation as one based on implicit obligations and trust. According to this perspective, employees are willing to exchange work performance for additional, less tangible values, such as feelings of being valued and supported (Eisenberger et al. 2001). Social exchange theory has been widely studied through research on perceived organisational support (POS) (Eisenberger et al. 2001; Harris, Harris and Harvey 2007; Muse and Stamper 2007). One can define POS as 'the extent to which employees perceive that their contributions are valued by their organisation and that their firm cares about their well-being' (Eisenberger et al. 1986, p. 501). It is a general concept for the organisational support provided by the employer. This POS can take the form of investments in employee development, which improves worker employability (cf. Lee and Bruvold 2003). Following Tsui, Pearce, Porter and Tripoli (1997) and Lee and Bruvold (2003), we focus on the perceptions of employees of the support they receive in their personal development. We refer to these as perceived support in employee development (PSED), which we define as the extent to which employees perceive that their employer supports their competence development.

Employee turnover leads to high costs of recruiting and training new employees. Moreover, organisational forgetting (Darr, Argote and Epple 1995) and a reduction of morale among remaining employees are common negative consequences of excessive turnover (Lee and Bruvold 2003; Benson et al. 2004). Therefore, firms attempt to reduce this turnover by increasing employee commitment through supporting their personal development. Looking at the employer-employee relationship as a social exchange relation, we expect employees to respond to this perceived support by a low intention to quit. This is because low intention to quit can be regarded as a way in which employees repay their firms for the care and contribution to their employability. We therefore formulate the subsequent hypothesis:

Hypothesis 2 (H2): $\quad$ PSED is negatively related to intention to quit. 


\section{The indirect effect of general training on turnover intention via PSED}

Social exchange theory provides insights that stand in contrast to the human capital perspective on the relation between training and turnover. Employers who train their employees in general skills signal that they are willing to invest in the competences of their employees, thus making themselves attractive employers. Employees who are able to participate in general training perceive that their employer cares about their employability and that they are valued by the organisation (Tannenbaum, Mathieu, Salas and CannonBowers 1991; Lee and Bruvold 2003; Sieben 2007). Studies taking a social exchange perspective have indeed provided evidence for a negative relation between training participation and turnover behaviour (Arthur 1994; Whitener 2001; Hung and Wong 2007); however, they did not distinguish between general and specific training.

PSED is created through the employees' evaluation of their organisation's dedication to support them in acquiring new general skills, knowledge and competences. Because of they feel they are supported in their own development by their employer, employees have less intention to quit. Investments in general training can therefore be perceived by employees as a signal that their organisation values them individually rather than only as employees within the organisation (Galunic and Anderson 2000). We therefore formulate the following hypothesis:

Hypothesis $3(\mathrm{H} 3)$ : $\quad$ Participation in general training has a positive effect on PSED.

As general training is expected to have a positive effect on PSED (H3) and PSED, on its turn, is expected to have a negative effect on intention to quit $(\mathrm{H} 2)$, we argue that from a social exchange perspective, the hypothesised positive effect of general training on intention to quit (H1) merely reflects the social exchange between the employer and the employee and is therefore fully mediated by PSED:

Hypothesis 4 (H4): PSED fully mediates the relation between employee participation in general training and intention to quit.

\section{The indirect effect of PSED on turnover intention via job satisfaction}

A number of studies have indicated that employee development positively affects levels of job satisfaction (Edgar and Geare 2005; Georgellis and Lange 2007). Therefore, it can be conceived that the level of job satisfaction is also affected by PSED. Employees who believe that dedicated organisations provide development opportunities for the benefit of the employees are expected to behave reciprocally (Eisenberger et al. 2001; Lee and Bruvold 2003; Georgellis and Lange 2007). Studies on social exchange theory by Guest (2002) and Hung and Wong (2007) have investigated how POS and compliance with the psychological contract affects job satisfaction, and they have found POS to be positively related to job satisfaction. Furthermore, Georgellis and Lange (2007) found that due to the perception of a breach in the psychological contract, women in Germany showed a lower level of job satisfaction.

We argue that PSED can affect job satisfaction in three ways. First, organisations that are supportive in developing their employees can induce their employees to feel emotionally attached to the organisation. In this way, organisations are able to enhance the psychological contract between employees and employer, which can result in more satisfied employees (Georgellis and Lange 2007). Second, employees will perceive that the organisation in which they are employed is concerned for the maintenance or growth of the competences of the workforce. This line of reasoning is supported by Shields and 
Ward (2001), who found that dissatisfaction with restricted training opportunities has a stronger impact on job satisfaction than dissatisfaction with workload and pay. Third, the possibility to develop new skills and competences enhances the level of the employees' employability both within and outside the firm (Lee and Bruvold 2003). This discussion leads to the following hypothesis:

Hypothesis 5 (H5): $\quad$ PSED is positively related to employee job satisfaction.

Job satisfaction, one of the most researched work-related variables, has been shown to negatively influence undesirable employee behaviour, such as absenteeism and turnover intention (Bartlett 2001; Winterton 2004; Hung and Wong 2007). There is also empirical evidence that in a sample of a related occupational group (British nurses), the overall dissatisfaction with the job is a major predictor of intention to quit (Shields and Ward 2001). We will test whether this expected relation holds in the occupational field we analyse. We advance the following hypothesis:

Hypothesis 6 (H6): Job satisfaction is negatively related to intention to quit.

Muse and Stamper (2007) found that job satisfaction is a mediating variable between POS and task and contextual performance, whereas Herrbach et al. (2004) showed that job satisfaction mediates the relation between the perceived external prestige of the organisation and turnover intention. From Hypotheses 5 and 6, we can derive that the hypothesised relation between PSED and the employees' intention to quit may be mediated by employee job satisfaction. We expect this mediation to be partial, as there is no theoretical argument that job satisfaction should fully mediate the relation between PSED and the intention to quit. Hence, we test the following hypothesis:

Hypothesis 7 (H7): The negative relationship between PSED and employee intention to quit is partially mediated by job satisfaction.

The hypotheses that will be tested in this article are summarised in Figure 1, where the main variable of interest - intention to quit - is in boldface, the effects to be estimated are represented by the letters $a$ through $e$ and the mediating variables are presented in the dotted boxes. According to H1, we expect a positive effect of training in general skills $(a>0)$, and according to $\mathrm{H} 2$, we expect a negative effect of PSED on intention to quit $(b<0)$. Following H3, we expect a positive effect of training in general skills on PSED

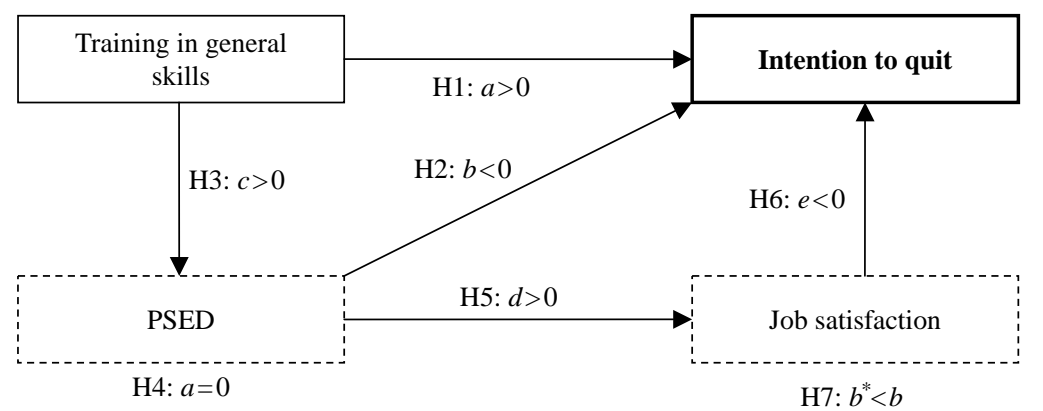

Figure 1. Hypothetical model for the effect of training in general skills, PSED and job satisfaction on the intention to quit.

Notes: The box in boldface represents the main variable of interest. The dashed boxes represent mediating variables. The effects to be tested are represented by the letters $a$ through $e$. 
$(c>0)$. Because of these expected relations, we also expect $(\mathrm{H} 4)$ that the effect of training in general skills on intention to quit is fully mediated by PSED $(a=0)$ : The inclusion of PSED in the model is therefore expected to suppress the direct effect of training in general skills on intention to quit. According to H5, we expect a positive effect of PSED on job satisfaction $(d>0)$, but following H6, we expect a negative effect of job satisfaction on intention to quit $(e<0)$. However, we expect that the effect of PSED on intention to quit is mediated by job satisfaction (H7): Inclusion of job satisfaction in the model is therefore expected to reduce the direct effect of PSED on intention to quit $\left(b^{*}<b\right)$.

\section{Data and methodology}

\section{Data collection and sample}

For our analysis, we use a data-set of Dutch pharmacy employees. We focus on the 'core' workers in these firms, the pharmacy assistants, who represent $80 \%$ of the total labour force in pharmacies (De Grip and Sieben 2009). Focusing the analysis on the core workers has the advantage of identifying a category that is homogeneous in terms of educational background and profession.

The employee data-set was acquired by means of a survey among pharmacy assistants in the Netherlands at the beginning of 2008. We invited 6000 pharmacy assistants randomly selected from the administrative database of the Dutch pension fund for pharmacy workers (Pensioenfonds Medewerkers Apotheken (PMA)), in which all assistants must register - to take part in the survey. Invitations to participate in the survey were sent by email, when feasible, and contained a link to the online version of the questionnaire. A total of 2156 pharmacy assistants were contacted by email. The 3844 pharmacy assistants for whom no email address was known were invited by regular mail. Their invitations contained the printed version of the questionnaire and a link to the online version of the questionnaire. From the group of 6000 pharmacy assistants contacted, a total of 2833 responded. The response rate $(47 \%)$ was marginally higher for assistants who were contacted by email. In total, $70 \%$ responded to the online questionnaire and $30 \%$ to the paper version of the questionnaire. The respondents to the survey are representative of all Dutch pharmacy assistants with respect to their background characteristics. The only exception is their age, as the response probability is a slightly increasing function of age. A weighting scheme was therefore designed to correct for this, and the analytical sample was appropriately weighted.

\section{Measures}

Table 1 shows the means and standard deviations of the variables included in our research model. We discuss these descriptive statistics in the remainder of this section.

\section{Participation in general training}

In the pharmacy sector, training is very common: $85 \%$ of all pharmacy assistants followed one or more work-related training sessions in the past year. Our data-set shows that in the Dutch pharmacy sector, employers pay the full training costs for $92 \%$ of all training (Sieben, De Grip and Smits 2006). In the survey, we distinguished between training in general skills and training in firm- or sector-specific pharmaceutical skills. As in most other studies (e.g. Bassanini, Booth, Brunello, De Paola and Leuven 2007), training is assessed by whether employees participated in work-related courses in the previous year. We asked 


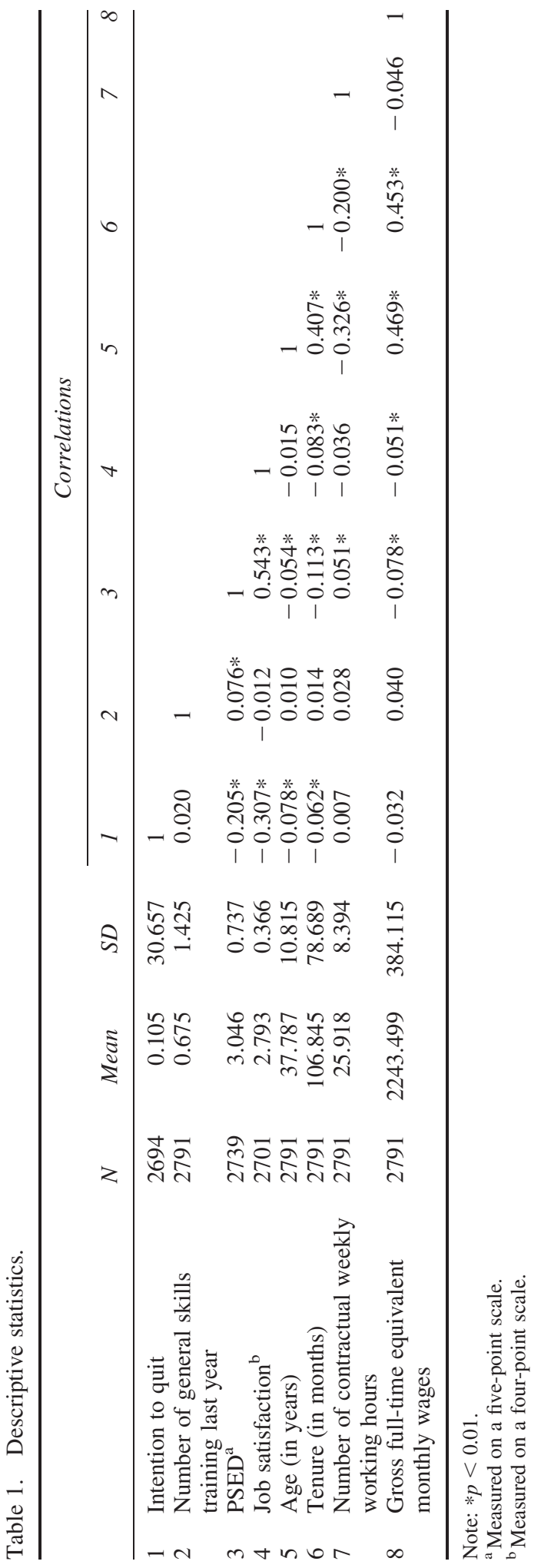


whether employees participated in a training course in 2007 with respect to 13 general skills derived from the competence scheme of the training fund of the Dutch pharmacy sector: communication skills, dealing with responsibilities, professionalism, problemsolving skills, being independent, being accurate, dealing with stress, leadership, interpersonal working skills, commercial skills, customer-orientation skills, planning skills and computer skills.

Participation in general training is measured as the sum of all the general skills training attended by an individual. We focus on these general skills because they are also of value in organisations outside the pharmacy sector. When employees acquire competences that are also valuable in other industries, they can switch to other jobs, as human capital theory predicts. In 2007, 30\% of pharmacy assistants participated in at least one general skills training course. In $50 \%$ of the cases, the general skills training was focussed on a single general skill. In $19 \%$ of cases, the training pertained to two general skills. In the remainder of the cases, the training was aimed at three or more general skills. Overall, the average number of general skills training courses taken by a pharmacy assistant in the past year was 0.68 .

\section{Perceived support in employee development}

Building on Tsui et al. (1997) and Lee and Bruvold (2003), we measure PSED by means of a seven-item scale for statements regarding the support employees receive in the domain of their personal development. We systematically include the encouragement and feedback of both the direct supervisor and the peers at work, spillover effects, as well as the content of the job. Employees used a five-point Likert scale ranging from 1 (do not agree at all) to 5 (fully agree) to rate their agreement with the following statements:

- My supervisor encourages me to transfer the learnt material to the work floor.

- My peers encourage me to transfer the learnt material to the work floor.

- I receive sufficient support from my supervisor.

- Everyone shares information with each other at work.

- I always get to hear when I successfully accomplished a task.

- I always get to hear how I could improve my working methods.

- I have to deal with tasks that are challenging.

We constructed a single measure of PSED based on the average of the respondents' answers. Cronbach's alpha for PSED was 0.748 , which supports the internal consistency of the construct.

\section{Job satisfaction}

Following Hackman and Oldham (1975), job satisfaction was measured on a four-point Likert scale, using six representative items. We measured general employee job satisfaction, as well as satisfaction with various aspects of the job as suggested in the literature, including satisfaction with job security, pay, work atmosphere, supervision and career perspectives (Hackman and Oldham 1975; Alexandrov, Babakus and Yavas 2007). We also included satisfaction with the job performance appraisal system. This item is important for the pharmacy sector, as it was introduced only recently to assess how assistants function in their jobs. The scales ranged from 1 (not satisfied at all) to 4 (very satisfied). We constructed a single measure of job satisfaction based on the average of the 
respondents' answers to the various items. Cronbach's alpha for these six indicators of job satisfaction was 0.728 .

\section{Intention to quit}

Intention to quit is verified to be a direct antecedent of turnover (Steel and Ovalle 1984; Herrbach et al. 2004). Intention to quit is often, but not exclusively, based on three-item (Cammann, Fischmann, Jenkins and Klesh 1979) or four-item scale (Hackman and Oldham 1976; see also Campbell and Campbell 2003). Here, we follow the approach of recent papers (Shields and Ward 2001; Robinson and Pillemer 2007; Antecol and Cobb-Clark 2009) and measure intention to quit directly by a single item: Are you currently looking for a job? We argue that a single-item scale for intention to quit is not problematic in a sample of only women, as it is more homogeneous than in a sample containing both genders. However, in our interpretation, we should keep in mind that the reliability of single-item measures is unknown (Miller and Wheeler 1992).

At the time of survey, around $10.5 \%$ of pharmacy assistants appeared to be looking for another job (see Table 1). This compares well with actual job mobility in the sector, as our computations on the administrative database of PMA show that, within 2 years, $10.6 \%$ of all assistants change employers. In an additional analysis, we use the different answer categories to distinguish between (1) workers' intention to quit for a similar job in another firm within the pharmacy sector and (2) their intention to quit for another occupation. Of all respondents, $5.3 \%$ envisaged quitting for another pharmacy and 5.2\% for an occupation outside the pharmacy sector.

\section{Control variables}

In our empirical analysis, we control for several individual characteristics of pharmacy assistants that have been shown to affect job satisfaction and intention to quit in earlier research: age, job tenure, contractual working hours and gross monthly wages in full-time working hours. These variables were not measured in the survey but were obtained from the administrative database of the PMA and matched to the respondents. As shown in Table 1, pharmacy assistants are on average 38 years old, have a tenure of about 107 months in the firm in which they are currently employed, earn gross monthly wages of approximately €2244 and work on average about $26 \mathrm{~h}$ a week. To account for the decreasing returns to experience and tenure, age appears linearly and in quadratic form in the models, while the logarithm of tenure is used in the model. The gross monthly wage is also included in logarithm in the model.

Table 1 also shows the correlations between the various variables. As expected, participation in general training is significantly and positively related to PSED (0.076). In addition, PSED is positively related to job satisfaction (0.543), but negatively related to employees' intention to quit $(-0.200)$.

\section{Methodology}

We test the hypotheses by means of ordinary least squares (OLS) regression and logistic hierarchical regression analyses. We use OLS to test the relations between general training and PSED and between PSED and job satisfaction. Logistic regression is required if the dependent variable is not linearly scaled, which is the case with employee intention to quit. Therefore, logistic regression is used to test associations with our main dependent 
variable. To complement this analysis, we distinguish between intention to quit for a similar occupation in another pharmacy and intention to quit for an occupation outside the pharmacy sector. This distinction is modelled within a multinomial logit framework.

This study tests for the mediating role of PSED and job satisfaction by means of hierarchical logistic regression analysis. Four requirements need to be fulfilled to indicate mediation: First, the independent variable must be significantly related to the dependent variable. Second, the independent variable should significantly predict the mediating variable. Third, the mediating variable should be a significant predictor of the dependent variable. Fourth, the effect of the independent variable on a dependent variable should be reduced when the mediator is included in the analysis. Moreover, when the coefficient of the independent variable is no longer significant when the mediator is included, there is strong evidence for a dominant mediator (Herrbach et al. 2004).

\section{Results}

\section{Training, PSED and intention to quit}

Table 2 shows the estimation results with respect to the hypothesised relations between general training participation and intention to quit and the mediating effect of PSED in this relation. The following relations are tested: that between general training participation and intention to quit (column 1, H1), between PSED and intention to quit (column 2, H2), between training and PSED (column 3, H3) and the mediating effect of PSED in the relation between general training and intention to quit (column 4, H4). The estimates

Table 2. Training, PSED and intention to quit: estimation results ( $t$ statistics in parentheses).

\begin{tabular}{|c|c|c|c|c|}
\hline & $\begin{array}{l}\text { (1) Test of } \mathrm{Hl} \\
\text { Intention to quit }\end{array}$ & $\begin{array}{l}\text { (2) Test of } \mathrm{H} 2 \\
\text { Intention to quit }\end{array}$ & $\begin{array}{l}\text { (3) Test of H3 } \\
\text { PSED }\end{array}$ & $\begin{array}{l}\text { (4) Test of } \mathrm{H} 4 \\
\text { Intention to quit }\end{array}$ \\
\hline \multirow{2}{*}{$\begin{array}{l}\text { Number of general } \\
\text { skills training }\end{array}$} & 0.054 & & $0.040 * * *$ & $0.097 * *$ \\
\hline & (1.34) & & (4.18) & (2.35) \\
\hline PSED & & $\begin{array}{c}-0.997 * * * \\
(-10.50)\end{array}$ & & $\begin{array}{c}-1.018 * * * \\
(-10.63)\end{array}$ \\
\hline Age & $\begin{array}{c}0.153 * * * \\
(2.75)\end{array}$ & $\begin{array}{c}0.150 * * * \\
(2.60)\end{array}$ & $\begin{array}{l}-0.020 * \\
(-1.84)\end{array}$ & $\begin{array}{c}0.144 * * \\
(2.49)\end{array}$ \\
\hline Age squared (/100) & $\begin{array}{c}-0.225 * * * \\
(-3.19)\end{array}$ & $\begin{array}{c}-0.225 * * * \\
(-3.09)\end{array}$ & $\begin{array}{c}0.025 * \\
(1.89)\end{array}$ & $\begin{array}{c}-0.218 * * * \\
(-2.98)\end{array}$ \\
\hline Tenure $(\log )$ & $\begin{array}{l}-0.149 * * \\
(-2.33)\end{array}$ & $\begin{array}{c}-0.213 * * * \\
(-3.20)\end{array}$ & $\begin{array}{c}-0.065 * * * \\
(-4.35)\end{array}$ & $\begin{array}{c}-0.216 * * * \\
(-3.22)\end{array}$ \\
\hline \multirow[t]{2}{*}{$\begin{array}{l}\text { Number of contractual } \\
\text { working hours }\end{array}$} & 0.000 & 0.003 & 0.003 & 0.002 \\
\hline & $(0.03)$ & $(0.33)$ & $(1.40)$ & $(0.21)$ \\
\hline \multirow[t]{2}{*}{$\begin{array}{l}\text { Gross full-time } \\
\text { equivalent wage (log) }\end{array}$} & -0.050 & -0.055 & -0.024 & -0.056 \\
\hline & $(-0.61)$ & $(-0.65)$ & $(-1.21)$ & $(-0.67)$ \\
\hline Constant & $\begin{array}{c}-3.546 * * * \\
(-3.25)\end{array}$ & $\begin{array}{l}-0.296 \\
(-0.25)\end{array}$ & $\begin{array}{l}3.781 * * * \\
(16.34)\end{array}$ & $\begin{array}{l}-0.129 \\
(-0.11)\end{array}$ \\
\hline$N$ & 2692 & 2689 & 2737 & 2689 \\
\hline $\begin{array}{l}\text { Adjusted } R^{2} \\
\text { Pseudo } R^{2}\end{array}$ & 0.019 & 0.085 & 0.019 & 0.088 \\
\hline
\end{tabular}

Notes: $* p<0.10, * * p<0.05, * * * p<0.01$.

${ }^{\mathrm{a}}$ Logit model for intention to quit, beta coefficients.

${ }^{\mathrm{b}}$ OLS regression for PSED. 
enable us to test the two contrary theoretical perspectives on the relation between participation in general training and employees' intention to quit.

Table 2 shows that participation in general training is positively related to pharmacy assistants' intention to quit. However, this effect is not statistically significant $(\beta=0.054$, $p>0.10)$. This finding is not in line with the human capital perspective; hence, Hypothesis 1 is rejected. However, PSED is significantly negatively related to intention to quit $(\beta=-0.007, p<0.01)$, which is in line with Hypothesis 2 . As expected, from social exchange theory, participation in general training is positively associated with PSED $(\beta=0.040, p<0.01)$. This supports Hypothesis 3 . In the final model, PSED is significantly negatively related to the intention to quit $(\beta=-1.018, p<0.01)$. However, in that model, PSED does not appear to fully mediate the effect of general training on intention to quit. Therefore, Hypothesis 4 can be rejected.

\section{Mediating role of job satisfaction}

The above analysis has shown that social exchange theory better explains employees' intention to quit. However, it remains to be seen whether this finding still holds when we control for the hypothesised mediating effect of job satisfaction. The first requirement that needs to be fulfilled when testing for mediation was met when we tested Hypothesis 2: PSED is significantly associated with employee intention to quit. The second requirement to be met is that PSED has a positive and significant effect on job satisfaction (H5). This hypothesis is tested in column 1 of Table 3. The third requirement is that job satisfaction be negatively related to quit intention (H6). This hypothesis is tested in column 2 of

Table 3. Job satisfaction, PSED and intention to quit: estimation results ( $t$ statistics in parentheses).

\begin{tabular}{lccc}
\hline & $\begin{array}{c}\text { (1) Test of H5 } \\
\text { Job satisfaction }\end{array}$ & $\begin{array}{c}\text { (2) Test of H6 } \\
\text { Intention to quit }^{b}\end{array}$ & $\begin{array}{c}\text { (3) Test of H7 } \\
\text { Intention to quit }^{b}\end{array}$ \\
\hline PSED & $0.274 * * *$ & & $-0.267 * *$ \\
Job satisfaction & $(33.72)$ & & $(-2.38)$ \\
Number of general skills training & & $-3.020 * * *$ & $-2.734 * * *$ \\
& & $(-15.31)$ & $(-11.98)$ \\
Age & & & 0.064 \\
& $-0.012 * *$ & $0.123 * *$ & $(1.45)$ \\
Age squared (/100) & $(-2.53)$ & $(2.02)$ & $0.121 * *$ \\
& $0.015 * * *$ & $-0.195 * *$ & $-0.194 * *$ \\
Tenure (log) & $(2.60)$ & $(-2.53)$ & $(-2.50)$ \\
& -0.010 & $-0.246 * * *$ & $-0.253 * * *$ \\
Number of contractual working hours & $(-1.57)$ & $(-3.51)$ & $(-3.59)$ \\
& $-0.005 * * *$ & -0.015 & -0.013 \\
Gross full-time equivalent wage (log) & $(-5.46)$ & $(-1.51)$ & $(-1.35)$ \\
& 0.013 & 0.001 & -0.008 \\
Constant & $(1.50)$ & $(0.01)$ & $(-0.09)$ \\
& $2.238 * * *$ & $5.629 * * *$ & $5.704 * * *$ \\
$N$ & $(21.72)$ & $(4.20)$ & $(4.25)$ \\
Adjusted $R^{2}$ & 2694 & 2690 & 2687 \\
Pseudo $R^{2}$ & 0.305 & & \\
\hline
\end{tabular}

Notes: $* p<0.10, * * p<0.05, * * * p<0.01$.

${ }^{a}$ OLS regression for job satisfaction.

${ }^{\mathrm{b}}$ Logit model for intention to quit, beta coefficients. 
Table 3. Finally, controlling for job satisfaction should reduce the effect of PSED on intention to quit (column 3, H7).

The estimation results in Table 3 show that PSED is significantly and positively correlated to job satisfaction $(\beta=0.274, p<0.01)$. This finding is in line with Hypothesis 5 . Job satisfaction is significantly and negatively $(\beta=-3.020, p<0.01)$ related to employee intention to quit: The higher the level of satisfaction, the lower the intention to quit. This finding is in line with Hypothesis 6 and supports the third requirement for establishing a mediating effect: The mediating variable is a significant predictor of the dependent variable.

In the final model (column 3 of Table 3), when we include all variables of interest (PSED, job satisfaction and general skills training), the effect of PSED decreases in size and significance from $\beta=-1.018(p<0.01)$ in column 3 of Table 2 to $\beta=-0.267$ $(p<0.05)$ in column 3 of Table 3. Therefore, we can conclude that job satisfaction functions as a partial mediator: Most of the impact of PSED on employee intention to quit is transferred through employee job satisfaction. This finding is in line with Hypothesis 7. Interestingly, in the full model, the effect of general skills training is insignificant.

With respect to the control variables included in the analysis, we find that employee intention to quit is significantly related to age and job tenure.

\section{Multinomial analysis of turnover intention}

The above findings raise another interesting question: Is this effect of PSED on turnover intention the same for quits to other employers in the sector as it is for quits to another sector? The results are reported in Table 4. When we split turnover intention into (1) the intention to quit for a similar job at another pharmacy and (2) the intention to quit the pharmacy for

Table 4. Intention to quit to a similar pharmacy job and intention to quit to another occupation outside the pharmacy branch: estimation results $(t \text { statistics in parentheses })^{\mathrm{a}}$.

\begin{tabular}{lcc}
\hline & Quit for other pharmacy & Quit to other occupation \\
\hline PSED & -0.180 & $-0.377 * *$ \\
& $(-1.20)$ & $(-2.47)$ \\
Job satisfaction & $-2.390 * * *$ & $-2.636 * * *$ \\
& $(-8.29)$ & $(-9.27)$ \\
Number of general skills training & 0.028 & $0.092 *$ \\
& $(0.45)$ & $(1.71)$ \\
Age & $0.182 * *$ & 0.082 \\
& $(2.18)$ & $(1.00)$ \\
Age squared (/100) & $-0.283 * * *$ & -0.138 \\
& $(-2.62)$ & $(-1.36)$ \\
Tenure (log) & $-0.354 * * *$ & -0.137 \\
& $(-4.07)$ & $(-1.37)$ \\
Number of contractual working hours & -0.009 & -0.014 \\
& $(-0.66)$ & $(-1.07)$ \\
Gross full-time equivalent wage $(\log )$ & -0.076 & 0.105 \\
& $(-0.75)$ & $(0.62)$ \\
Constant & $3.713 * *$ & $4.253 * *$ \\
& $(2.18)$ & $(2.25)$ \\
$N$ & 2687 & \\
Pseudo $R^{2}$ & 0.1442 & \\
\hline
\end{tabular}

Notes: $* p<0.10, * * p<0.05, * * * p<0.01$

${ }^{a}$ Multinomial logit model for intention to quit (reference is no intention to quit), beta coefficients. 
another occupation, PSED only has a significant negative effect on the latter $(\beta=-0.377$, $p<0.05)$. When pharmacy assistants perceive their employers to be supportive of their personal development, they have less intention to quit for another occupation. Remarkably, this perception does not influence their quit intention for another pharmacy in any significant way. In both cases, however, job satisfaction is significantly and negatively correlated with intention to quit. As to the effect of general skills training in this model, it appears to have a significant and negative effect on intention to quit to an occupation outside the pharmacy sector, as human capital theory would suggests $(\beta=-0.092)$. However, this effect is only weakly significant $(p<0.10)$.

\section{Conclusions}

This study analysed whether the investments of Dutch pharmacies in the general competences of their employees stimulate or restrict their personnel turnover. As in most other service sectors, general competences have become increasingly important in the Dutch pharmacy sector. Human capital theory postulates that investments in general skills will increase personnel turnover. However, according to social exchange theory, employees perceive general skills training in particular as a gift because it increases their marketability outside the sector in which they are employed. We did not find any evidence for the prediction of human capital theory that employees' intention to quit is positively related to participation in general training. This confirms earlier findings of Chew and Chan (2008). However, additional analyses that distinguish between quit intention to another pharmacy and quit intention to an occupation outside the sector show that general skills training is negatively correlated with the latter only. Although the significance is weak, this finding is in line with human capital theory predictions.

On the basis of social exchange theory, we predicted that general skills training would positively affect PSED. Pharmacy assistants indeed perceive that general training investments signal an employer's care for their employability and consider being loyal as a way to reciprocate. However, PSED has a significant negative effect only on assistants' quit intentions for occupations outside the pharmacy sector and not on their quit intention for similar jobs in other pharmacies. This finding shows that their loyalty is actually sector specific rather than pharmacy specific. Moreover, PSED does not fully mediate the effect of general skills training on employees' intentions to quit.

Our analysis of the mediating role of job satisfaction in the relation between PSED and the intentions of pharmacy assistants to quit shows that job satisfaction acts as a strong mediator. It seems that the negative relation between PSED and assistants' intention to quit is to a large extent - but not fully - mediated by their level of job satisfaction. This finding is in line with those of Shields and Ward (2001) and Winterton (2004). It also suggests that the important role of job satisfaction should be taken into account when designing skill development practices for pharmacy assistants.

\section{Discussion and implications}

The Dutch pharmacy sector is a highly interesting sector for studying the relation between PSED and turnover intention, because HRD practices are central to the human resource practices in this sector (De Grip and Sieben 2009). Moreover, increasing shortages of pharmacy assistants are expected within the next few years. Therefore, it is of great interest to investigate whether the investments of firms in this sector in the general competences of their employees stimulate or restrict personnel turnover. In particular, examining the effect of general skills is highly relevant, because such skills have become 
increasingly important within service sector firms such as in the pharmacy branch. For example, recent changes within the sector - more demanding clients and increased competition with independent drugstores (De Grip, Sieben and Stevens 2006) - require pharmacy assistants to be more customer oriented and to have better commercial and communication skills. However, the training provided to pharmacy assistants often focuses on sector-specific skills that increase pharmaceutical knowledge. The transferability of these skills is therefore restricted to other pharmacies.

This study contributes to the literature in several ways. First, our analysis incorporates the contrary hypotheses of human capital theory and social exchange theory. Our study builds on Sieben (2007), who contrasted the human capital and social exchange perspectives in an analysis on the relation between training participation and labour turnover. We extend her analysis by taking into account employee perceptions of their employer's support and job satisfaction. Second, Lee and Bruvold (2003) addressed the impact of employee perceptions of investments in their development. However, hardly any research has been conducted so far on how employee perceptions of their organisation's willingness to contribute to their development influence subsequent behaviour and attitudes. Third, this study transferred the concept of POS (Eisenberger et al. 1986) to the specific domain of perceived investment in employee development. This enabled us to focus on the specific role of employee perceptions on a supportive climate regarding their development, that is, PSED.

\section{Limitations and further research suggestions}

Industry studies have a great advantage, in that they can focus on a rather homogeneous workforce. However, our results need to be reproduced in other industries for validation. Moreover, because our data-set consisted solely of female workers, it would be interesting to reproduce our analysis in sectors of industry that are dominated by male workers.

As the data we used were cross-sectional, our results may have been exposed to causal ambiguity. It is possible, for example, that more satisfied pharmacy assistants incite pharmacists to provide more development possibilities, support and feedback. Furthermore, it may take time before an increase in general competences affects employee turnover intention. It would therefore be interesting to replicate this study within a longitudinal design. Such a design would make it possible to determine the sustainability of the relations between PSED and positive work attitudes and behaviour.

\section{Acknowledgements}

We would like to thank Bas van Diepen and Piet Van den Bossche from Maastricht University and an anonymous reviewer for their useful comments on an earlier version of this article.

\section{References}

Alexandrov, A., Babakus, E., and Yavas, U. (2007), 'The Effects of Perceived Management Concern for Frontline Employees and Customers on Turnover Intentions,' Journal of Service Research, 9, 356-371.

Antecol, H., and Cobb-Clark, D. (2009), 'Racial Harassment, Job Satisfaction, and Intentions to Remain in the Military,' Journal of Population Economics, 22, 713-738.

Arthur, J.B. (1994), 'Effects of Human Resource Systems on Manufacturing Performance and Turnover,' Academy of Management Journal, 37, 670-687.

Bartlett, K.R. (2001), 'The Relationship Between Training and Organizational Commitment: A Study in the Health Care Field,' Human Resource Development Quarterly, 12, 335-352. 
Bassanini, A., Booth, A., Brunello, G., De Paola, M., and Leuven, E. (2007), 'Workplace Training in Europe,' in Education and Training in Europe, eds. G. Brunello, P. Garibaldi and E. Wasmer, Oxford: Oxford University Press, pp. 143-309.

Becker, G.S. (1962), 'Investment in Human Capital: A Theoretical Analysis,' Journal of Political Economy, 70, 9-49.

Bedeian, A.G., Kemery, E.R., and Pizzolatto, A.B. (1992), 'Career Commitment and Expected Utility of Present Job as Predictors of Turnover Intentions and Turnover Behaviour,' Journal of Vocational Behaviour, 39, 331-352.

Benson, G.S., Finegold, D., and Mohrman, S.A. (2004), 'You Paid for the Skills, Now Keep Them: Tuition Reimbursement and Voluntary Turnover,' Academy of Management Journal, 47, 315-331.

Bishop, J. (1997), 'What We Know About Employer-Provided Training: A Review of the Literature,' Research in Labor Economics, 16, 19-87.

Blau, P. (1964), Exchange and Power in Social Life, New York: Wiley.

Cammann, C., Fischmann, M., Jenkins, D., and Klesh, J. (1979), 'The Michigan Organizational Assessment Questionnaire,' unpublished manuscript, Ann Arbor, MI, University of Michigan.

Campbell, D., and Campbell, K. (2003), 'Global Versus Facet Predictors of Intention to Quit: Differences in a Sample of Male and Female Singaporean Managers and Non-managers,' International Journal of Human Resource Management, 14, 1152-1177.

Chew, J., and Chan, C. (2008), 'Human Resources Practices, Organizational Commitment and Intention to Stay,' International Journal of Manpower, 29, 503-522.

Clark, A., Georgellis, Y., and Sanfey, P. (1998), 'Job Satisfaction, Wage Changes, and Quits,' Research in Labor Economics, 17, 95-121.

Darr, E.D., Argote, L., and Epple, D. (1995), 'The Acquisition, Transfer and Depreciation of Knowledge in Service Organizations: Productivity in Franchises,' Management Science, $41,1750-1762$.

De Grip, A., and Sieben, I. (2009), 'The Effectiveness of More Advanced Human Resource Systems in Small Firms,' International Journal of Human Resource Management, 20, 1914-1928.

De Grip, A., Sieben, I., and Stevens, F. (2006), Vocational Versus Communicative Competencies as Predictors of Job Satisfaction, ROA-RM-2006/3, Maastricht: Maastricht University.

Edgar, F., and Geare, A. (2005), 'HRM Practice and Employee Attitudes: Different MeasuresDifferent Results,' Personnel Review, 34, 534-549.

Eisenberger, R., Armeli, S., Rexwinkel, R., Lynch, P.D., and Rhoades, L. (2001), 'Reciprocation of Perceived Organizational Support,' Journal of Applied Psychology, 86, 42-51.

Eisenberger, R., Huntington, R., Hutchison, S., and Sowa, D. (1986), 'Perceived Organizational Support,' Journal of Applied Psychology, 71, 500-507.

Galunic, D.C., and Anderson, E. (2000), 'From Security to Mobility: Generalized Investments in Human Capital and Agent Commitment,' Organizational Sciences, 11, 1-20.

Georgellis, Y., and Lange, T. (2007), 'Participation in Continuous On-the-Job Training and Job Satisfaction: Longitudinal Evidence From the German Labour Market,' International Journal of Human Resource Management, 18, 969-985.

Green, F., Felstead, A., Mayhew, K., and Pack, A. (2000), 'The Impact of Training on Labour Mobility: Individual and Firm-Level Evidence From Britain,' British Journal of Industrial Relations, 38, 261-275.

Guest, D. (2002), 'Human Resource Management, Corporate Performance and Employee Wellbeing: Building the Worker into HRM,' Journal of Industrial Relations, 44, 335-358.

Hackman, J., and Oldham, G. (1975), 'Development of the Job Diagnostic Survey,' Journal of Applied Psychology, 60, 159-170.

Hackman, J., and Oldham, G. (1976), 'Motivation Through the Design of Work: Test of a Theory,' Organizational Behavior and Human Performance, 16, 250-279.

Harris, R.B., Harris, K.J., and Harvey, P. (2007), 'A Test of Competing Models of the Relationships Among Perceptions of Organizational Politics, Perceived Organizational Support, and Individual Outcomes,' Journal of Social Psychology, 147, 631-651.

Herrbach, O., Mignimac, K., and Gatignon, A.-L. (2004), 'Exploring the Role of Perceived External Prestige in Managers' Turnover Intentions,' International Journal of Human Resource Management, 15, 1390-1407. 
Hung, H., and Wong, Y.H. (2007), 'The Relationship Between Employer Endorsement of Continuing Education and Training and Work in Study Performance: A Hong Kong Case Study,' International Journal of Training and Development, 11, 295-313.

Lee, C.H., and Bruvold, N.T. (2003), 'Creating Value for Employees: Investment in Employee Development,' International Journal of Human Resource Management, 14, 981-1000.

Martin, G., Pate, J., and McGoldrick, J. (1999), 'Do HRD Investment Strategies Pay? Exploring the Relationship Between Lifelong Learning and Psychological Contracts,' International Journal of Training and Development, 3, 200-214.

Miller, J., and Wheeler, K. (1992), 'Unraveling the Mysteries of Gender Differences in Intentions to Leave the Organization,' Journal of Organizational Behavior, 13, 465-478.

Muse, L.A., and Stamper, C.L. (2007), 'Perceived Organizational Support: Evidence for a Mediated Association With Work Performance,' Journal of Managerial Issues, 19, 517-535.

Robinson, J., and Pillemer, K. (2007), 'Job Satisfaction and Intention to Quit Among Nursing Home Nursing Staff: Do Special Care Units Make a Difference?' Journal of Applied Gerontology, 26, $95-112$.

Shields, M.A., and Ward, M.E. (2001), 'Improving Nurse Retention in the British National Health Service: The Impact of Job Satisfaction on the Intentions to Quit,' Journal of Health Economics, 20, 677-701.

Sieben, I. (2007), 'Does Training Trigger Turnover-Or Not? The Impact of Formal Training on Graduates' Job Search Behaviour,'Work, Employment and Society, 21, 397-416.

Sieben, I., De Grip, A., and Smits, W. (2006), Arbeidsmarktmonitor Apotheekbranche 2005-2006, Nieuwegein: SBA.

Steel, R., and Ovalle, N. (1984), 'A Review and Meta-analysis of Research on the Relationship between Behavioral Intentions and Employee Turnover,' Journal of Applied Psychology, 69, 673-686.

Tannenbaum, S.I., Mathieu, J.E., Salas, E., and Cannon-Bowers, J.A. (1991), 'Meeting Trainees' Expectations: The Influence of Training Fulfillment on the Development of Commitment, Self-Efficacy, and Motivation,' Journal of Applied Psychology, 76, 759-769.

Tsai, W.-C., and Tai, W.-T. (2003), 'Perceived Importance as a Mediator of the Relationship Between Training Assignment and Training Motivation,' Personnel Review, 32, 151-163.

Tsui, A.S., Pearce, J.L., Porter, L.W., and Tripoli, A.M. (1997), 'Alternative Approaches to the Employer-Employee Relationship: Does Investment in Employees Pay Off?' Academy of Management Journal, 40, 1089-1121.

Wayne, S.J., Shore, M., and Liden, R.C. (1997), 'Perceived Organizational Support and Leader-Member Exchange: A Social Exchange Perspective,' Academy of Management Journal, 40, 82-111.

Whitener, E.M. (2001), 'Do "High Commitment" Human Resource Practices Affect Employee Commitment? A Cross-Level Analysis Using Hierarchical Linear Modelling,' Journal of Management, 27, 515-535.

Winterton, J. (2004), 'A Conceptual Model of Labour Turnover and Retention,' Human Resource Development International, 7, 371-390. 